\title{
Vaccination against influenza among pregnant women in southern Brazil and associated factors
}

\author{
Vacinação contra Influenza entre gestantes no Sul do Brasil \\ e fatores associados
}

Raúl Andrés Mendoza-Sassi (https://orcid.org/0000-0002-4641-9056) ${ }^{1}$

Angélica Ozório Linhares (http://orcid.org/0000-0002-3526-9427) ${ }^{2}$

Franciane Maria Machado Schroeder (https://orcid.org/0000-0003-4643-4624) ${ }^{1}$

Nathalia Matties Maas (https://orcid.org/0000-0001-6949-8351) ${ }^{1}$

Seiko Nomiyama (https://orcid.org/0000-0001-5194-9636) ${ }^{1}$

Juraci Almeida César (https://orcid.org/0000-0003-0864-0486) ${ }^{1}$

${ }^{1}$ Faculdade de Medicina, Universidade Federal do Rio Grande. R. Gal. Osório s/n, Centro. 96200-000 Rio Grande RS Brasil. ramsassi@gmail.com ${ }^{2}$ Faculdade de Nutrição, Universidade Federal de Pelotas. Pelotas RS Brasil.

\begin{abstract}
This article aims to identify the prevalence and factors associated with influenza vaccination in pregnant women. This is a cross-sectional study conducted in a municipality in the southernmost region of Brazil, which included all women giving birth in 2016. The outcome was having received the vaccine against influenza during pregnancy. Sociodemographic, behavioral and prenatal care characteristics and morbidities were analyzed. The analysis included sample description, the prevalence of vaccination for each independent variable and a multivariate analysis. Two thousand six hundred ninety-four pregnant women were interviewed, of which $53.9 \%$ reported having been vaccinated. Factors associated with increased prevalence of vaccination were mother's higher schooling, prenatal care, tetanus vaccination and prenatal care performed in a public service. On the other hand, prenatal care onset after the first quarter reduced the prevalence of vaccination. The results point to the need to reinforce the importance of vaccination against influenza among pregnant women and among health professionals, regardless of the severity of the current epidemiological setting.
\end{abstract}

Key words Influenza vaccine, Human influenza, Pregnant women, Risk factors, Vaccine coverage
Resumo $O$ objetivo deste artigo é identificar a prevalência da imunização contra a gripe em mulheres grávidas e seus fatores associados. Estudo transversal realizado em um município no extremo sul do Brasil, que incluiu todas as mulheres que deram à luz no ano de 2016. O desfecho foi ter recebido a vacina contra a gripe durante a gravidez. Características sociodemográficas, comportamentais, do pré-natal e morbidades foram analisadas como fatores associados à vacinação. A análise constou de descrição da amostra, prevalência da vacinação para cada uma das variáveis independentes e análise multivariada. Foram entrevistadas 2.694 parturientes, das quais 53,9\% informaram ter recebido a vacina. Os fatores associados a uma maior prevalência de imunização foram: maior escolaridade materna, realização do pré-natal, ter realizado a vacina antitetânica e fazer o pré-natal em um serviço público. Por outro lado, o início do pré-natal após o primeiro trimestre reduziu a prevalência de imunização. Os resultados apontam para a necessidade de reforçar a importância da imunização contra a Influenza entre mulheres grávidas e entre profissionais da saúde, independentemente da gravidade do atual cenário epidemiológico.

Palavras-chave Vacina contra a gripe, Influenza humana, Mulheres grávidas, Fatores de risco, Cobertura de vacinação 


\section{Introduction}

Influenza is an acute and highly contagious viral infection with a worldwide distribution. It occurs seasonally and often in the form of a pandemic, as in 2009. An estimated 3 to 5 million cases and around 250-300,000 deaths occur annually worldwide because of it $^{1}$.

Groups that are most at risk and develop the most severe forms of the disease are children, the elderly, people with chronic and immunosuppressive diseases and pregnant women. With regard to this latter group, there is evidence that pregnant women who are infected suffer a greater number of hospitalizations, premature births and higher mortality ${ }^{2}$. Studies also show that mothers' vaccination reduces the incidence of influenza, with clear benefits to the mother and the baby and no reports of serious adverse effects ${ }^{3,4}$.

The vaccination strategy against influenza in Brazil was incorporated in 1999 for the elderly, within the National Vaccination Program. As of 2010, because of the pandemic virus A (H1N1) pmd09, the recommendation was extended to other at-risk groups, including pregnant wom$\mathrm{en}^{5}$. Thus, annual campaigns were established before the seasonal months of the disease, with coverage targets set at $80 \%$ for all groups.

Despite being an effective vaccine and with few adverse effects, the coverage observed in several countries and in the different risk groups, particularly in pregnant women, is $\operatorname{low}^{6-12}$. This variability is due to the effect of the various factors associated with the probability of vaccination, such as sociodemographic characteristics ${ }^{7,11-15}$, reproductive history $y^{6-10}$, prenatal care ${ }^{15}$, cultural factors ${ }^{16}$ and health system ${ }^{17,18}$. Coverage varies widely across countries, ranging from 6.2 to $85.7 \%$.

The evaluation of coverage through production data, obtained by calculating the proportion of vaccines administered by population group (estimated by census data or other records), while easy to perform, underestimates the actual coverage $^{19}$. Therefore, it is very important to perform population-based studies that allow a more accurate estimate. These studies also facilitate the identification of groups that are less likely to be vaccinated and factors that involve non-vaccination.

Thus, this study aimed to analyze the prevalence of influenza vaccination and associated factors, based on a population survey that included all pregnant women who gave birth in 2016 in a municipality in the southernmost region of Brazil.

\section{Material and methods}

The study is part of a larger project, which includes all pregnant women and is carried out every three years since 2007 , in order to study the care received by pregnant women and newborns. The project's middle-sized municipality is located in the southernmost region of Brazil and had an estimated population of 208,641 inhabitants $^{20}$ for 2016. In that year, the municipality had 29 Primary Health Care Facilities and coverage by the Family Health Strategy was $57.3 \%{ }^{21}$. This is a cross-sectional study on all pregnant women who had children between January 1 and December 31, 2016. Pregnant women were interviewed within 48 hours of delivery. All mothers-to-be living in urban or rural areas of the municipality, with 20 weeks gestational age or more or whose newborn had a birth weight of 500 grams or more were eligible. The study's statistical power was $80 \%$ to find a relative risk (RR) of at least 1.5 , using a $95 \%$ confidence level, a prevalence of non-exposed of at least $10 \%$, and a non-exposed to exposed ratio of at least 6:1.

A standard and pre-coded questionnaire was used to collect information on different characteristics of pregnant women. The following information was retrieved: a) sociodemographic: mother's age $(<20,20-29$ and $\geq 30$ years $)$, referred skin color (white and black/other), marital status (with our without a partner), schooling (1-3, 4-8, 9-11 and $\geq 12$ full years of study) and per capita household income for the last month (income distribution in quartiles); b) behavioral: smoking during pregnancy (at least one cigarette), drinking alcohol during pregnancy (at least one drink), and practicing physical exercise during pregnancy (leisure-time physical exercise); c) pregnancy and prenatal care: multiparous, type of delivery (normal or cesarean), number of prenatal consultations, trimester onset of prenatal care, type of service in which care was provided (public or private), tetanus vaccination in the current or previous pregnancy; d) referred morbidities before or during pregnancy: asthma, arterial hypertension and diabetes.

The dependent variable was immunization against influenza and was investigated by the following question: "During this pregnancy, were you vaccinated against influenza?" If the answer was yes, another question was asked about the month in which she was vaccinated and whether she had to pay to be vaccinated, the corresponding month of pregnancy and in which service she was vaccinated. The trivalent vaccine consisted 
of A (H1N1), A (H3N2) and B virus was offered routinely and free of charge by the Ministry of Health during the vaccination campaign. In Rio Grande do Sul, it was offered from April 25 to May 20, 2016, after which it remained available in all UBS until doses ran out. It was also possible to receive paid vaccine in private clinics and laboratories.

The information collection was performed by four interviewers trained for the research who daily identified the hospital records and pregnant women admitted to delivery. After the pregnant women agreed to participate and signed the Informed Consent Form, the questionnaire was applied. The study received approval of the human research ethic committee.

The collection tool was an electronic questionnaire with software created for this purpose and typed in a Tablet. At the end of each day, data were transmitted by two independent typists to the University server using the RedCap ${ }^{\circledR} \mathrm{Web}^{22}$ platform. A third person supervised the transferred data. Discrepancies such as mistakes in completing or missing answers were listed and corrected and, if necessary, new contact with the new mother was established, either face-to-face or by telephone, in order to clarify concerns.

The analyzes consisted, first in a descriptive analysis, where the means and standard deviations for the continuous variables and the proportions for the categorical variables were calculated. In the case of influenza vaccination, the prevalence and its 95\% confidence interval (CI95\%) were estimated. Vaccination-associated factors were analyzed by calculating the Crude and Adjusted Prevalence Ratios (PR) and their respective CI95\%, using the Poisson regression with robust variance adjustment ${ }^{23}$. The statistical tests used to assess significance were Wald's linear trend test and Wald's test for heterogeneity. A multivariate backward analysis was adopted and variables inserted following a hierarchical four-level analysis model ${ }^{24}$. The adoption of the four hierarchical levels was based on which factors would be distal or proximal in terms of outcome determination. The sociodemographic variables, which are macro factors in terms of determination, entered at the first level. At the second level were the behavioral variables, which intermediate the effect of sociodemographic factors and in turn may determine the implementation of prenatal care. Prenatal care realization, type of delivery and multiparity variables, which are determined by the antecedents and can determine prenatal characteristics and morbidities, entered at the third level. Finally, in the fourth level, where only those who received prenatal care were analyzed, the variables that affect the vaccination more proximally were introduced: those related to the prenatal care and morbidities that advise immunization. Variables of each level were adjusted to each other. Those with a value of $\mathrm{p}<0.20$ were maintained to adjust with the variables of the next level, as a way to avoid possible positive confusion. Statistical analysis were performed in the Stata ${ }^{\circledR}$ version $14^{25}$ program. In all statistical tests, a $\mathrm{p}<0.05$ value was adopted from a two-tailed test.

\section{Results}

In 2016, in the municipality of Rio Grande, 2,710 pregnant women gave birth and were eligible for this study. Of these, 2,694 accepted to be interviewed (99.4\%) and of this total, 2,670 answered the question about influenza vaccination (98.5\%), resulting in $1.5 \%$ of losses. Vaccination coverage against influenza was 53.9\% (CI95\% $52.0-55.8$ ), with $23.3 \%$ vaccinated the first quarter, $34.3 \%$ in the second and $42.4 \%$ in the third. Most were vaccinated in the public sector (96.5\%) and did not pay for the vaccine (96.7\%) (data not shown in Table 1). The main characteristics of puerperal women are shown in Table 1.

Table 1. Characteristics of pregnant women who gave birth in 2016. Rio Grande, RS, Brazil, 2016 (N $=2,670$ ).

\begin{tabular}{lrc}
\hline \multicolumn{1}{c}{ Variable } & N & \% \\
\hline Mother's age (2666) & 449 & 16.84 \\
$<$ 20 years & 1,328 & 49.81 \\
20 to 29 years & 889 & 33.35 \\
30 years or more & & \\
Referred skin color (2,662) & 845 & 31.74 \\
Black/other & 1,817 & 68.26 \\
White & & \\
Full schooling years (2,670) & 37 & 1.39 \\
1 to 3 & 946 & 35.43 \\
4 to 8 & 1,058 & 39.63 \\
9 to 11 & 629 & 23.55 \\
12 or more & \multicolumn{2}{c}{ it continues }
\end{tabular}


Table 1. Characteristics of pregnant women who gave birth in 2016. Rio Grande, RS, Brazil, 2016 (N $=2,670)$.

\begin{tabular}{|c|c|c|}
\hline Variable & $\mathbf{N}$ & $\%$ \\
\hline \multicolumn{3}{|c|}{$\begin{array}{l}\text { Household income per capita } \\
(2,497)\end{array}$} \\
\hline $1^{\text {st }}$ quartile (poorest) & 625 & 25.03 \\
\hline $2^{\text {nd }}$ quartile & 673 & 26.95 \\
\hline $3^{\text {rd }}$ quartile & 581 & 23.27 \\
\hline $4^{\text {th }}$ quartile (richest) & 618 & 24.75 \\
\hline \multicolumn{3}{|l|}{ With partner $(2,669)$} \\
\hline No & 435 & 16.30 \\
\hline Yes & 2,234 & 83.70 \\
\hline \multicolumn{3}{|l|}{ Smoker $(2,669)$} \\
\hline No & 2,378 & 89.10 \\
\hline Yes & 291 & 10.90 \\
\hline \multicolumn{3}{|c|}{$\begin{array}{l}\text { Alcoholic beverage consumption } \\
(2,667)\end{array}$} \\
\hline No & 2,624 & 98.39 \\
\hline Yes & 43 & 1.61 \\
\hline \multicolumn{3}{|c|}{ Engaged in physical exercise (2668) } \\
\hline No & 2,515 & 94.27 \\
\hline Yes & 153 & 5.73 \\
\hline \multicolumn{3}{|c|}{ Performed prenatal care $(2,670)$} \\
\hline No & 40 & 1.50 \\
\hline Yes & 2,630 & 98.50 \\
\hline \multicolumn{3}{|l|}{ Delivery type $(2,670)$} \\
\hline Normal & 1,223 & 45.81 \\
\hline Cesarean & 1,447 & 54.19 \\
\hline
\end{tabular}

Table 1. Characteristics of pregnant women who gave birth in 2016. Rio Grande, RS, Brazil, 2016 (N $=2,670$ ).

\begin{tabular}{|c|c|c|}
\hline Variable & $\mathbf{N}$ & $\%$ \\
\hline \multicolumn{3}{|l|}{ Multiparous $(2,670)$} \\
\hline No & 1,145 & 42.88 \\
\hline Yes & 1,525 & 57.12 \\
\hline \multicolumn{3}{|l|}{$\begin{array}{l}\text { Prenatal care: } 6 \text { or more } \\
\text { consultations }(2,610)\end{array}$} \\
\hline No & 377 & 14.44 \\
\hline Yes & 2,233 & 85.56 \\
\hline \multicolumn{3}{|l|}{$\begin{array}{l}\text { Prenatal care trimester of onset } \\
(2,609)\end{array}$} \\
\hline $1^{\text {st }}$ & 2,071 & 79.38 \\
\hline $2^{\text {nd }}$ & 492 & 18.86 \\
\hline $3^{\text {rd }}$ & 46 & 1.76 \\
\hline \multicolumn{3}{|l|}{ Prenatal care location $(2,591)$} \\
\hline Public service & 1,462 & 56.43 \\
\hline Private service & 1,129 & 43.57 \\
\hline \multicolumn{3}{|l|}{ Received tetanus vaccine $(2,629)$} \\
\hline No & 575 & 21.87 \\
\hline Yes, before current pregnancy & 434 & 16.51 \\
\hline Yes, during current pregnancy & 1,620 & 61.62 \\
\hline \multicolumn{3}{|l|}{ Asthma $(2,669)$} \\
\hline No & 2,144 & 80.33 \\
\hline Yes & 525 & 19.67 \\
\hline \multicolumn{3}{|l|}{ Hypertension $(2,668)$} \\
\hline No & 2,179 & 81.67 \\
\hline Yes & 489 & 18.33 \\
\hline \multicolumn{3}{|l|}{ Diabetes $(2,665)$} \\
\hline No & 2,545 & 95.50 \\
\hline Yes & 120 & 4.50 \\
\hline
\end{tabular}

Table 2 shows crude and adjusted PR. There was an increased prevalence of vaccination with increased mother's schooling ( $\mathrm{p}$ linear trend = 0.01 ), and it was $17 \%$ higher in the group with schooling equal to or greater than 12 years compared to the group of lower schooling. Age, per capita income, skin color and marital status did not affect the occurrence of vaccination. None of the behavioral factors was significantly associated after adjustment. Prenatal care, increased the prevalence of vaccination by $600 \%$. A significant inverse association between the trimester onset of prenatal care and vaccination was observed.
Those who did it in the second reduced the prevalence of vaccination by $12 \%$ and those who did it in the latter reduced by $52 \%$, compared to those who started in the first. The delivery of prenatal care in a private service lowered $15 \%$ the prevalence of vaccination compared to the public service. Those vaccinated against tetanus before the current pregnancy had increased influenza vaccination by $35 \%$, and those vaccinated during the current pregnancy had increased by $61 \%$ (p of linear trend $<0.01)$ None of the diseases studied affected the prevalence of vaccination (Table 2 ). 
Table 2. Crude and adjusted analyses for influenza vaccination in pregnant women who delivered in 2016 and associated factors, Rio Grande, RS, Brazil, 2016. N = 2670.

\begin{tabular}{|c|c|c|c|c|c|c|}
\hline \multirow{2}{*}{ Level } & \multirow{2}{*}{ Variable } & \multirow{2}{*}{ Prevalence } & \multicolumn{2}{|c|}{ Crude analysis } & \multicolumn{2}{|c|}{ Adjusted analysis } \\
\hline & & & PR (CI 95\%) & P-Value & PR (CI 95\%) & P-value \\
\hline \multirow[t]{20}{*}{$1^{\text {st }}$} & Mother's age (years) & & & 0.86 & & $0.17^{\mathrm{a}}$ \\
\hline & $<20$ & 54.57 & 1 & & 1 & \\
\hline & 20 to 29 & 53.69 & $0.98(0.89-1.08)$ & & $0.93(0.84-1.03)$ & \\
\hline & $\geq 30$ & 53.88 & $0.99(0.89-1.09)$ & & $0.91(0.81-1.02)$ & \\
\hline & Self-referred skin color & & & 0.46 & & 0.89 \\
\hline & Blak/other & 52.90 & 1 & & 1 & \\
\hline & White & 54.43 & $1.03(0.95-1.11)$ & & $0.99(0.92-1.07)$ & \\
\hline & Schooling (full years) & & & $0.01^{\mathrm{a}}$ & & $0.01^{\mathrm{a}}$ \\
\hline & 1 to 3 & 48.65 & 1 & & 1 & \\
\hline & 4 to 8 & 50.42 & $1.04(0.74-1.45)$ & & $1.02(0.73-1.44)$ & \\
\hline & 9 to 11 & 55.67 & $1.14(0.82-1.60)$ & & $1.15(0.82-1.60)$ & \\
\hline & $\geq 12$ & 56.44 & $1.16(0.83-1.63)$ & & $1.17(0.83-1.64)$ & \\
\hline & Household income per capita & & & $0.37^{\mathrm{b}}$ & & $0.50^{\mathrm{b}}$ \\
\hline & $1^{\text {st }}$ quartile (poorest) & 52.96 & 1 & & 1 & \\
\hline & $2^{\text {nd }}$ quartile & 54.53 & $1.03(0.93-1.14)$ & & $0.99(0.90-1.10)$ & \\
\hline & $3^{\text {rd }}$ quartile & 52.50 & $0.99(0.89-1.10)$ & & $0.93(0.83-1.05)$ & \\
\hline & $4^{\text {th }}$ quartile (richest) & 56.31 & $1.06(0.96-1.18)$ & & $0.98(0.87-1.10)$ & \\
\hline & With partner & & & 0.09 & & 0.10 \\
\hline & No & 50.11 & 1 & & 1 & \\
\hline & Yes & 54.66 & $1.09(0.98-1.21)$ & & $1.09(0.98-1.21)$ & \\
\hline \multirow[t]{9}{*}{$2^{\text {nd }}$} & Smoker & & & 0.03 & & 0.23 \\
\hline & No & 54.71 & 1 & & 1 & \\
\hline & Yes & 47.42 & $0.87(0.76-0.98)$ & & $0.96(0.88-1.04)$ & \\
\hline & Consumed alcoholic beverage & & & 0.06 & & 0.09 \\
\hline & No & 54.19 & 1 & & 1 & \\
\hline & Yes & 37.21 & $0.67(0.46-1.01)$ & & $0.71(0.48-1.05)$ & \\
\hline & Performed physical exercise & & & 0.55 & & 0.89 \\
\hline & No & 53.80 & 1 & & 1 & \\
\hline & Yes & 56.21 & $1.04(0.90-1.21)$ & & $1.01(0.87-1.17)$ & \\
\hline \multirow[t]{9}{*}{$3^{\text {rd }}$} & Performed prenatal care & & & $<0.01$ & & $<0.01$ \\
\hline & No & 7.50 & 1 & & 1 & \\
\hline & Yes & 54.60 & $7.28(2.45-21.63)$ & & $6.65(2.25-19.67)$ & \\
\hline & Multiparous & & & 0.01 & & 0.22 \\
\hline & No & 57.03 & 1 & & 1 & \\
\hline & Yes & 51.54 & $0.90(0.84-0.97)$ & & $0.95(0.87-1.03)$ & \\
\hline & Delivery type & & & 0.43 & 1 & 0.73 \\
\hline & Normal & 53.07 & 1 & & $0.99(0.92-1.06)$ & \\
\hline & Cesarean & 54.60 & $1.03(0.96-1.10)$ & & & \\
\hline
\end{tabular}

\section{Discussion}

The study identified that vaccination coverage was $53.9 \%$. The probability of vaccination increased with antenatal care and improved linearly with increasing mother's education and with 


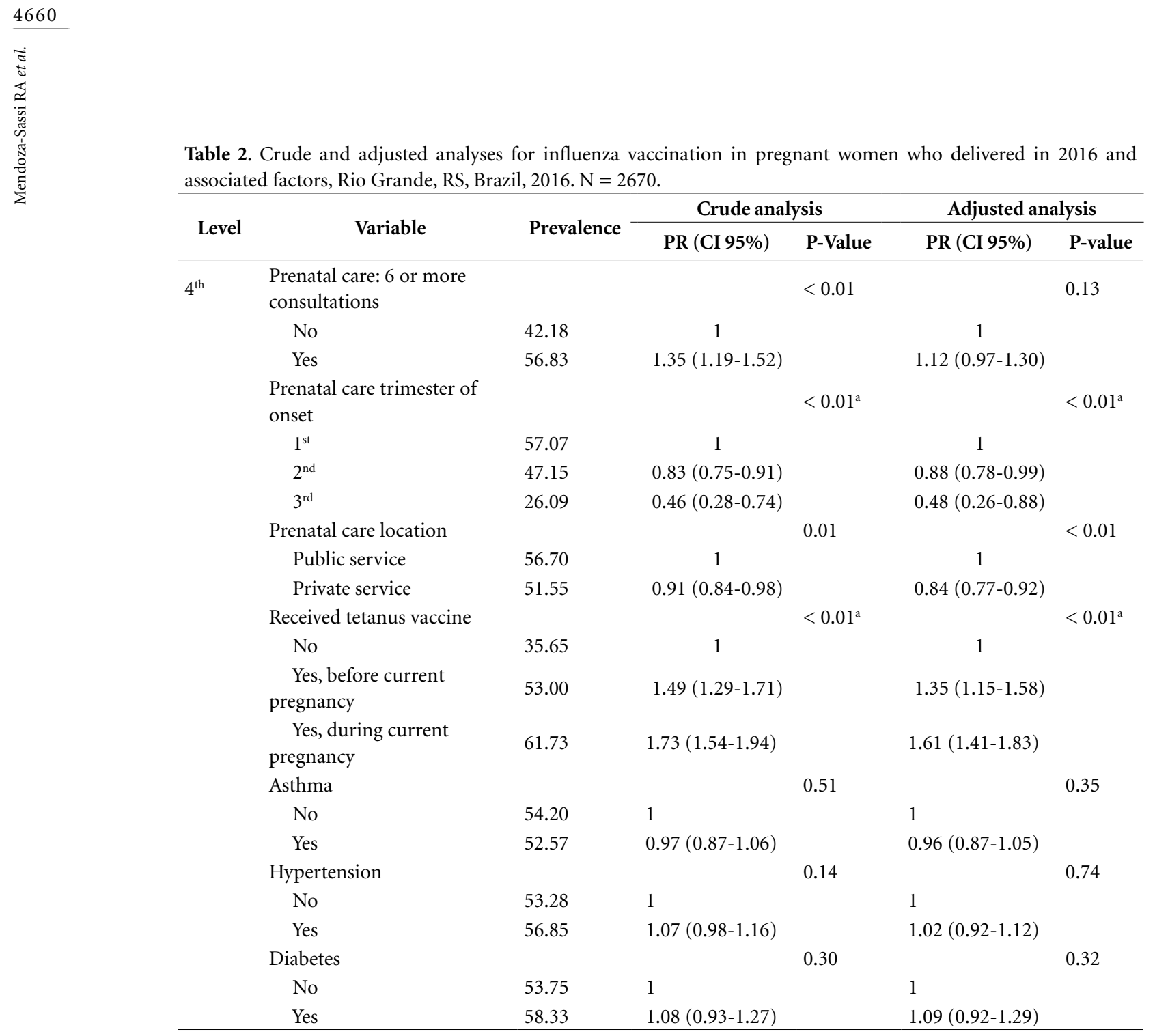

a Linear trend test. b Wald's test for heterogeneity. PR: Prevalence Ratio. CI: Confidence Interval. 1st level $\mathrm{n}=2.670 ; 2 \mathrm{nd}$ level $\mathrm{n}=2.670$; 3rd level $\mathrm{n}=2.670$; $4 \mathrm{o}$ level $=2.570$.

erage expected for the campaign period. In that year, the coverage for pregnant women in the state of Rio Grande do Sul calculated from the doses applied was $75.3 \%{ }^{26}$, higher than that found in this study. This difference can be explained by the methodological difference between the calculation of the coverage based on the estimates of the target populations and the calculation based on the individual information ${ }^{19}$.

The proximity of vaccination campaigns with epidemics or more severe pandemics tends to increase the coverage and this can be observed in the case of vaccination against influenza in Brazil. A study ${ }^{29}$ conducted in the same municipality in 2010 and using the same methodology as the current one identified a coverage of $77 \%$, or $43 \%$ higher than in 2016. This study was carried out in the year following the 2009 pandemic produced by the virus A (H1N1) pmd09, when there was great media mobilization informing about the severity of the situation. Apparently, outside the pandemic and during seasonal periods, there is a decrease in the perception of risk by pregnant women and a lower recommendation of the vaccine by health professionals ${ }^{30,31}$, and these are factors that tend to curb coverage.

In this study, prevalence increased linearly with the categories of schooling, becoming 17\% higher in the group with 12 years or more of study in relation to the 1-3 years group, and this finding is consistent with the scientific literature ${ }^{7,11,27}$. The mechanism that induces this increase must be related to the better access and better processing of the information that pregnant women with more schooling possess. On the other hand, income did not affect vaccination in this study, 
possibly because the vaccine was offered free of charge by the public health system.

Behavioral variables, smoking and alcohol intake, which in other studies were associated with a lower probability of vaccination ${ }^{10,15} \mathrm{did}$ not have a significant effect in this study. The two variables may be factors related to the profile of health behavior that pregnant women may have. The lack of statistical power may be a reason for the lack of association observed.

The factor with the greatest effect on vaccination was having received prenatal care. Most parturient studied (98.5\%) received this care and the vaccination coverage of this group was $54.6 \%$. In the group of women who did not perform prenatal care, the prevalence of vaccination dropped to $7.5 \%$. This difference should be reflecting the opportunity that the pregnant woman has to receive the recommendation of health professionals during contact with the health service ${ }^{11,27,30,31}$, which does not happen with the pregnant woman who does not perform prenatal care.

The vaccination policy adopted by the country is another aspect that affects vaccination ${ }^{27}$. In Brazil, there is a clearly expressed policy to promote vaccination among at-risk groups, and national campaigns are launched annually, offering the vaccine free of charge, which may explain the greater coverage compared to other countries. In this study, $96.0 \%$ of the women were vaccinated by the public health system, facilitating access to the Vaccine Coverage falls substantially in countries where the health system does not offer free vaccination $^{18}$.

An remarkable aspect observed in this study is that the probability of vaccination decreases as the prenatal trimester increases. This result is consistent with that observed in another study ${ }^{32}$. This association may be related to both the better health behavior of pregnant women who initiate the prenatal care at the right time, and a longer time of contact with the service and recommendations of health professionals, in such a way that the prevalence of vaccination increases.

The prevalence of vaccinating against influenza increased proportionately with the timing of vaccination against tetanus, which may be showing once again the health behavior of pregnant women influencing vaccination.

An increased vaccination status among pregnant women with morbidities such as asthma, high blood pressure and diabetes was expected, since these are situations that also recommend vaccination. However, this association was not found, and literature ${ }^{15,33}$ shows that results are not consistent in this regard.

With regard to the type of provider who offered prenatal care, it was found that the pregnant women who were monitored in the public service were more likely to be vaccinated. This may be due to a more widespread stance among health professionals of the Brazilian public network to recommend the Vaccine This type of professional follows the health care protocols defined by the Ministry of Health, which includes recommending vaccination of pregnant women against influenza, which may not be the case for private services health professionals.

Some possible methodological limitations may affect the observed results. One of them is that the information on the accomplishment of the influenza vaccine and associated factors was obtained by pregnant women's report and not through medical records. On the other hand, data were retrieved through interviews performed in the immediate postpartum period, reducing the probability of memory bias. In addition, there is evidence for another type of outcome, also related to pregnancy ${ }^{34}$, that the information reported by pregnant women is valid. Another plausible limitation to this occurrence is the lack of statistical power to find a significant difference in some associations, particularly in the relationship between alcohol consumption and smoking with vaccination. Another aspect to consider is that, since this is a cross-sectional study, results cannot be interpreted as determinant factors, but only as associations. Finally, because this study is carried out in a middle-sized Brazilian municipality, findings cannot be extrapolated to all municipalities. However, it may be reflecting the situation of municipalities with similar characteristics.

The study found coverage below the expected goal of vaccination against influenza in a middle-sized Brazilian municipality. To increase coverage, vaccination must be recommended by all health professionals related to prenatal care, both in the public and private systems. Health managers must also program actions to increase vaccination among pregnant women with lower levels of schooling and those starting prenatal care after the first trimester. The recommendation should be widely disseminated and formulated so that all vaccines are applied during pregnancy. 


\section{Collaborations}

RA Mendoza-Sassi participated in the design of the study, analysis and interpretation of the data, writing of the paper, review of the final article and approval of final version for publication, and agree to be accountable for all aspects of the work. JA César participated in the design of the study, review of the final article and approval the final version for publication and agree to be accountable for all aspects of the work. AO Linhares, FMM Schroeder, NM Maas and S Nomiyama participated in the analysis and interpretation of the data, writing of the article, final review and approval of final version for publication and agree to be accountable for all aspects of the work.

\section{References}

1. World Health Organization (WHO). Influenza (seasonal). Geneva: WHO; 2016.

2. Mertz D, Geraci J, Winkup J, Gessner BD, Ortiz JR, Loeb M. Pregnancy as a risk factor for severe outcomes from influenza virus infection: A systematic review and meta-analysis of observational studies. Vaccine 2017; 35(4):521-528.

3. Steinhoff MC, Omer SB. A review of fetal and infant protection associated with antenatal influenza immunization. Am J Obstet Gynecol 2012; 207(Supl. 3):S21-S27.

4. Naleway AL, Smith WJ, Mullooly JP. Delivering influenza vaccine to pregnant women. Epidemiol Rev 2006; 28:47-53.

5. Marreiros ACC, Teixeira AMS, Silva DA, Costa KC, Chaves MP, Silva RCMS, Rebelo RCF, Carvalho SMD, Pereira SF, Almeida WAF. Informe Técnico da 19a Campanha Nacional de Vacinação contra a Influenza. Brasília: Ministério da Saúde (MS); 2017.

6. Maher L, Hope K, Torvaldsen S, Lawrence G, Dawson A, Wiley K, Thomson D, Hayen A, Conaty S. Influenza vaccination during pregnancy: coverage rates and influencing factors in two urban districts in Sydney. Vaccine 2013; 31(47):5557-5564.

7. Laenen J, Roelants M, Devlieger R, Vandermeulen C. Influenza and pertussis vaccination coverage in pregnant women. Vaccine 2015; 33(18):2125-2131.

8. Ding H, Black CL, Ball S, Donahue S, Fink RV, Williams WW, Kennedy ED, Bridges CB, Lu PJ, Kahn KE, Dean AK, Grohskopf LA, Ahluwalia IB, Devlin R, DiSogra C, Walker DK, Greby SM. Influenza Vaccination Coverage Among Pregnant Women--United States, 2014-15 Influenza Season. MMWR Morb Mortal Wkly Rep 2015; 64(36):1000-1005.

9. Barber A, Muscoplat MH, Fedorowicz A. Coverage with Tetanus, Diphtheria, and Acellular Pertussis Vaccine and Influenza Vaccine Among Pregnant Women - Minnesota, March 2013-December 2014. MMWR Morb Mortal Wkly Rep 2017; 66(2):56-59.

10. Sammon CJ, McGrogan A, Snowball J, de Vries CS. Pandemic influenza vaccination during pregnancy: an investigation of vaccine uptake during the 2009/10 pandemic vaccination campaign in Great Britain. Hum Vaccin Immunother 2013; 9(4):917-923.

11. Drees M, Tambourelli B, Denstman A, Zhang W, Zent R, McGraw P, Ehrenthal DB. Sustained high influenza vaccination rates and decreased safety concerns among pregnant women during the 2010-2011 influenza season. Vaccine 2013; 31(2):362-366.

12. Yuen CY, Tarrant M. Determinants of uptake of influenza vaccination among pregnant women - a systematic review. Vaccine 2014; 32(36):4602-4613.

13. Gracie S, Metcalfe A, Dolan SM, Kehler H, Siever J, Tough S. Utilization of the $2009 \mathrm{H} 1 \mathrm{~N} 1$ vaccine by pregnant women in a pandemic year. J Obstet Gynaecol Can 2011; 33(2):127-133. 
14. Freund R, Le Ray C, Charlier C, Avenell C, Truster V, Tréluyer JM, Skalli D, Ville Y, Goffinet F, Launay O; Inserm COFLUPREG Study Group. Determinants of non-vaccination against pandemic $2009 \mathrm{H} 1 \mathrm{~N} 1$ influenza in pregnant women: a prospective cohort study. PLoS One 2011; 6:e20900.

15. Blondel B, Mahjoub N, Drewniak N, Launay O, Goffinet F. Failure of the vaccination campaign against $\mathrm{A}(\mathrm{H} 1 \mathrm{~N} 1)$ influenza in pregnant women in France: results from a national survey. Vaccine 2012; 30(38):5661-5665.

16. Wiley KE, Massey PD, Cooper SC, Wood NJ, Ho J, Quinn HE, Leask J. Uptake of influenza vaccine by pregnant women: a cross-sectional survey. Med J Aust 2013; 198(7):373-375.

17. Mak DB, Regan AK, Joyce S, Gibbs R, Effler PV. Antenatal care provider's advice is the key determinant of influenza vaccination uptake in pregnant women. Aust N Z J Obstet Gynaecol 2015; 55(2):131-137.

18. Lau JT, Cai Y, Tsui HY, Choi KC. Prevalence of influenza vaccination and associated factors among pregnant women in Hong Kong. Vaccine 2010; 28(33):53895397.

19. Moraes JC, Ribeiro MCA, Simões O, Castro PC, Barata RB. Qual é a cobertura vacinal real? Epidemio. Serv. Saúde 2003; 12(3):147-153

20. Instituto Brasileiro de Geografia e Estatística (IBGE). IBGE Cidades. Rio de Janeiro: IBGE; 2016.

21. Brasil. Ministério da Saúde (MS). Histórico de Cobertura da Saúde da Família. Brasília: MS; 2016.

22. Vanderbilt University. Research Electronic Data Capture Software. REDCap. Nashville: Vanderbilt University; 2016.

23. Barros AJ, Hirakata VN. Alternatives for logistic regression in cross-sectional studies: an empirical comparison of models that directly estimate the prevalence ratio. BMC Med Res Methodol 2003; 3:21.

24. Victora CG, Huttly SR, Fuchs SC, Olinto MT. The role of conceptual frameworks in epidemiological analysis: a hierarchical approach. Int J Epidemiol 1997; 26(1):224-227.

25. Stata Corporation. Stata Statistical Software: Release 14. College Station: StataCorp LLC; 2015.

26. Rio Grande do Sul. Secretaria da Saúde (SS). Informe Epidemiológico da Vigilância de Influenza. Porto Alegre: SS; 2016.

27. Yuen CYS, Fong DYT, Lee ILY, Chu S, Siu ES, Tarrant M. Prevalence and predictors of maternal seasonal influenza vaccination in Hong Kong. Vaccine 2013; 31(45):5281-5288.

28. Luteijn JM, Dolk H, Marnoch GJ. Differences in pandemic influenza vaccination policies for pregnant women in Europe. BMC Public Health 2011; 11:819.

29. Mendoza-Sassi RA, Cesar JA, Cagol JM, Duarte IA, Friedrich LM, Santos VK, Zhang L. 2010 A(H1N1) vaccination in pregnant women in Brazil: identifying coverage and associated factors. Cad Saude Publica 2015; 31(6):1247-1256.
30. Schmid P, Rauber D, Betsch C, Lidolt G, Denker ML. Barriers of Influenza Vaccination Intention and Behavior - A Systematic Review of Influenza Vaccine Hesitancy, 2005 - 2016. PLoS One 2017; 12:e0170550.

31. Wilson RJ, Paterson P, Jarrett C, Larson HJ. Understanding factors influencing vaccination acceptance during pregnancy globally: A literature review. Vaccine 2015; 33(47):6420-6429.

32. Loubet P, Guerrisi C, Turbelin C, Blondel B, Launay O, Bardou M, Goffinet F, Colizza V, Hanslik T, Kernéis S; GGNET study group. Influenza during pregnancy: Incidence, vaccination coverage and attitudes toward vaccination in the French web-based cohort G-GrippeNet. Vaccine 2016; 34(20):2390-2396.

33. van Lier A, Steens A, Ferreira JA, van der Maas NA, de Melker HE. Acceptance of vaccination during pregnancy: experience with 2009 influenza A (H1N1) in the Netherlands. Vaccine 2012; 30(18):2892-2899.

34. Natland ST, Andersen LF, Nilsen TI, Forsmo S, Jacobsen GW. Maternal recall of breastfeeding duration twenty years after delivery. BMC Med Res Methodol 2012; 12:179.

Artigo apresentado em 11/12/2017

Aprovado em 30/04/2018

Versão final apresentada em 02/05/2018 
